\title{
Nitrate Accumulation and Vegetable Quality
}

\author{
Ananya Chowdhury ${ }^{1}$, Ankan Das ${ }^{2}$ \\ ${ }^{1}$ Department of Horticulture, Institute of Agricultural Science, Calcutta University, Kolkata - 700019 (West Bengal) \\ ${ }^{2}$ Post Harvest Technology of Horticultural Crops, Faculty of Horticulture, Bidhan Chandra Krishi Viswavidyalaya, Mohanpur, 741252 , \\ Nadia, West Bengal, India
}

\begin{abstract}
Nitrogen is the main growth-limiting factor in most field crops. Farmers therefore use manure and nitrogen-based fertilizers to boost crop yields resulting vegetables accumulating high levels of nitrate which is now a worldwide problem. Ingested nitrate is converted in saliva and the gastrointestinal tract to the more toxic Nitrite and can lead to severe pathogenesis. The maximum allowable nitrate levels in vegetables should not exceed levels that reflect good agricultural practices. Therefore, an integrated collaboration among agronomists, physiologists, molecular biologists, farmers, consumers and policy-makers is the need of the hour and may yield satisfactory results towards minimizing accumulation of nitrate in plants and its subsequent consumption by human beings.
\end{abstract}

Keywords: nitrogen, nitrate, accumulation, pathogenesis, minimization

\section{Introduction}

Nitrate is a naturally occurring form of nitrogen and is an integral part of the nitrogen cycle in the environment. Nitrate is formed from fertilizers, decaying plants, manure and other organic residues. It is found in the air, soil, water and food (particularly in vegetables) and is produced naturally within the human body. It is also used as a food additive, mainly as a preservative and antimicrobial agent (Speijers, 1996). It is used in foods such as cheese and cheese products, raw and processed meats, edible casings, processed fish, fish products, spirits and liqueurs. Due to the increased use of synthetic nitrogen fertilizers and livestock manure in intensive agriculture, vegetables and drinking water may contain higher concentrations of nitrate than in the past.

\section{Sources of nitrate}

The three main sources of nitrate intakes are vegetables, water, cured meat (Walker, 1990). Vegetables constitute the major dietary source of nitrate, generally providing from 300 to $940 \mathrm{mgg}^{-1}$ of the daily dietary intake (Tables 1 ). Nitrite is found in plant foodstuffs, typically $1-2 \mathrm{mg} \mathrm{kg}^{-1}$ of fresh vegetable weight. Higher amounts of nitrite are found in contaminated food or in broken vegetable tissues in food stored for several days at room temperature (Santamaria, 1997).

Table 1: Estimated intakes of $\mathrm{NO}_{3}$ from sources other than food additives at the global level $\mu \mathrm{g} \mathrm{mg}^{-1}$ ) (Harrison, 2004)

\begin{tabular}{|l|l|l|l|l|l|}
\hline \multicolumn{1}{|c|}{ Regional diet } & ADI & Vegetables & Water & Cereals & Fruit \\
\hline Asian & 200 & 650 & 200 & 100 & 50 \\
\hline Far Eastern & 100 & 450 & 300 & 150 & 100 \\
\hline African & 100 & 300 & 400 & 150 & 100 \\
\hline Latin American & 250 & 650 & 150 & 50 & 100 \\
\hline European & 700 & 900 & 50 & $<50$ & 50 \\
\hline
\end{tabular}

*Based on $60 \mathrm{~kg}$ body weight

\section{Nitrate accumulation in vegetables}

Vegetables can impact health positively, their nitrate and nitrite levels should not be overlooked. Nitrogen is the main growth-limiting factor in most field crops and the major source in plants is mineralised nitrogen, as nitrate and ammonium. Farmers may therefore use manure and nitrogen-based fertilizers to boost crop yields. A range of leafy vegetables can accumulate high levels of nitrate. The concentrations depend on a range of factors including season, light, temperature, growing conditions, fertilizer use, and storage of the crop (Dich et al., 1996).

\section{Physiology of Nitrate accumulation}

Nitrate is mainly to be found in cell vacuoles and is transported in the xylem. The xylem carries water and nutrients from the roots to the leaves, while the phloem carries the products of photosynthesis from the leaves to the growth points of the plant (i.e. storage organs such as seeds or tubers). This means leaf crops such as cabbage, lettuce and spinach have fairly large nitrate concentrations whereas storage organs such as potato, carrot, and pea and beans have relatively small concentrations (EFSA, 2008). Applying nitrogen fertiliser increases nitrate concentrations in the xylem but has virtually no effect on concentrations in the phloem, and therefore leaf crops such as lettuce or cabbage show an increased concentration of nitrate in response to nitrogen fertiliser, except in their very youngest leaves, while storage organs such as peas and beans that are fed by the phloem tend to show little effect (EFSA, 2008).

\section{Factors responsible for nitrate accumulation}

\section{Nutritional factors}

Nitrate accumulation in vegetables often depends on the amount and kind of nutrients present in the soil and is closely related to the time of application, and the amount and composition of the fertilizers applied (Zhou et al., 2000). An adequate fertilization program may ensure sufficient plant growth without any risk of plant nitrate levels going too high (Vieira et al., 1998). Plants accumulate more nitrate as the nitrogen fertilization level increases (Chen et al., 2004;), whereas limiting the nitrogen availability reduces nitrate content significantly (McCall and Willumsen, 1999).

\section{Environmental factors}

The effect of climate on nitrate accumulation was studied by Grzebelus and Baranski (2001), who found that nitrate 


\section{International Journal of Science and Research (IJSR) \\ ISSN (Online): 2319-7064 \\ Index Copernicus Value (2013): 6.14 | Impact Factor (2014): 5.611}

content was less in the year that had a high rainfall. In warm and wet years, increased accumulation of nitrate is possible, regardless of whether the nitrogen originates from organic or mineral sources (Custic et al., 2003). Plant nitrate levels were influenced by weather conditions more significantly than by the form and application rates of fertilizers (Custic et al., 2003). Nitrate accumulation varies with the season (Vieira et al., 1998), being higher in autumn-winter than in spring (Santamaria et al., 1999).

\section{Light}

Nitrate accumulation is a complex process involving many physiological steps. Being involved in photosynthesis as well as in uptake, translocation and reduction of nitrate, the intensity of light has a crucial role in the regulation of nitrate accumulation (Merlo et al., 1994). Light intensity is inversely correlated to the nitrate content of plants; therefore, diurnal changes in light intensity might cause a diurnal nitrate accumulation pattern. Chadjaa et al., (2001) have studied the effect of artificial lighting in greenhouses on nitrate accumulation in lettuce. High-pressure sodium vapor lamps were more effective than metal halide lamps at increasing the nitrate reductase (NR) activity and reducing the nitrate accumulation.

\section{Genotypic variability}

The nitrate content varies markedly with plant species, cultivars of the same species, and even genotypes with different ploidy (Anjana et al., 2006). The shoot nitrate content is genetically determined and likely to be controlled by several genes (QTLs) (Harrison et al., 2004). The causal factors might include genetic differences among genotypes in enzymes of the nitrogen metabolic pathway (nitrate reductase/nitrite reductase), the rate of nitrate uptake, the rate of uptake of other elements needed for enzyme activity, or differences in generation of electron donors needed in the assimilative pathway that might lead to the observed variation in nitrate accumulation.

\section{Nitrate distribution within the plant}

Generally, nitrate-accumulating vegetables belong to the families of Brassicaceae (rocket, radish, mustard), Chenopodiaceae (beetroot, Swiss chard, spinach) and Amarantaceae; but also Asteraceae (lettuce) and Apiaceae (celery, parsley) include species with high nitrate contents (Table 2). The differing capacities to accumulate nitrate can be correlated with differing location of the nitrate reductase activity, as well as to differing degree of nitrate absorption and transfer in the plant (Maynard, 1979).

Table 2: Classification of vegetables according to $\mathrm{NO}_{3}$ content $\left(\mathrm{mg} \mathrm{kg}^{-1} \mathrm{fm}\right)$

\begin{tabular}{|c|c|}
\hline Content & Vegetables \\
\hline $\begin{array}{l}\text { Very low } \\
(<200)\end{array}$ & $\begin{array}{l}\text { artichoke, asparagus, broad bean, eggplant, } \\
\text { garlic, onion, melon, pea, potato, summer } \\
\text { squash, sweet potato, tomato, watermelon }\end{array}$ \\
\hline $\begin{array}{c}\text { Low } \\
(200-500)\end{array}$ & $\begin{array}{l}\text { broccoli, carrot, cauliflower, cucumber, } \\
\text { pumpkin, }\end{array}$ \\
\hline $\begin{array}{c}\text { Middle } \\
(500-1000)\end{array}$ & cabbage, turnip \\
\hline $\begin{array}{c}\text { High } \\
(1000-2500)\end{array}$ & $\begin{array}{l}\text { celeriac, Chinese cabbage, kohlrabi leek } \\
\text { parsley }\end{array}$ \\
\hline $\begin{array}{l}\text { Very high } \\
(>2500\end{array}$ & $\begin{array}{l}\text { celery, cress, lettuce, radish, beetroot, rocket, } \\
\text { spinach, swiss chard }\end{array}$ \\
\hline
\end{tabular}

Nitrate content differs in the various parts of a plant. Indeed, the vegetable organs can be listed by decreasing nitrate content as follows: petiole > leaf > stem > root > inflorescence > tuber > bulb > fruit > seed (Andrews, 1986).

\section{Storage and food processing}

The nitrite concentrations in fresh, undamaged vegetables are usually very low but under adverse post-harvest storage conditions nitrite concentration can increase in vegetables as a result of bacterial or endogenous nitrate reductase reducing the nitrate to nitrite (WHO, 2003). Under refrigerated storage, the endogenous nitrate reductase in vegetable is inactivated. However, high levels of nitrite have been found in home-made vegetable purees even after refrigerated storage for only 12 hours or more. Presumably pureeing releases endogenous nitrate reductase causing excessive formation of nitrite. Nitrite accumulation is inhibited under frozen storage. Different studies have shown reduction of nitrate levels (16 to $79 \%$ loss) when vegetables such as peas, cabbage, beans, carrots, potatoes spinach, endives and celery leaves are cooked in water. For potatoes, a study found that the greatest decrease in reducing nitrate (36-58\%) and nitrite (82-98\%) was observed when peeled potatoes were boiled in water compared to steaming.

\section{Nitrate toxicity}

High nitrate concentrations in vegetables is a worldwide problem. Very high concentration (over $5000 \mathrm{mg} / \mathrm{kg}$ ) of nitrate in vegetables especially leafy vegetables has been reported in different places such as Mainland China as well as various countries in Europe (Feng, 2006). Due to the increased use of synthetic nitrogen fertilisers and livestock manure in intensive agriculture, vegetables and drinking water may contain higher concentrations of nitrate than in the past.

\section{Kinetics and metabolism of nitrate toxicity}

Ingested nitrate is readily and completely absorbed from stomach and the upper small intestine. Nitrate is rapidly distributed throughout the tissues. In humans, about $25 \%$ of ingested nitrate is secreted in the saliva and approximately $20 \%$ of the secreted salivary nitrate is then converted to nitrite by microorganisms on the tongue and thus for normal individuals about $5-7 \%$ of ingested nitrate can be detected as salivary nitrite. However, for individuals with a high rate of conversion this figure maybe up to $20 \%$. The major site for nitrate reduction is at the base of the tongue where a stable, nitrate-reducing mircroflora is present. Oral reduction of nitrate is the most important source of nitrite for humans, and will account for approximately $70-80 \%$ of the human total nitrite exposure (WHO, 2003). Nitrate can be reduced to nitrite by both enteric bacteria and mammalian nitrate reductase activity. Many species of microorganism resident in the gastrointestinal tract have nitrate reductase activity. Therefore, bacterial reduction of nitrate may also take place in other parts of the human gastrointestinal tract, but not normally in the stomach; exceptions are reported in humans with low gastric acidity, such as artificially fed infants, certain patient in whom hydrochloric acid secretion is slower than normal, or patients using antacids. 


\section{International Journal of Science and Research (IJSR) \\ ISSN (Online): 2319-7064}

Index Copernicus Value (2013): 6.14 | Impact Factor (2014): 5.611

Absorbed nitrite is rapidly oxidized to nitrate in blood (WHO, 2003).

\section{Acute toxicity}

The acute oral toxicity of nitrate is generally low. It has been observed that the oral lethal dose of nitrate in humans is around $330 \mathrm{mg} / \mathrm{kg}$ body weight (ESPA, 2008).

\section{$\underline{\text { Methaemoglobinaemia }}$}

The major acute toxic effect of nitrite poisoning is methaemoglobinaemia.

$\mathrm{NO}_{2}^{-}+\operatorname{oxyHb}\left(\mathrm{Fe}^{2+}\right) \rightarrow \operatorname{metHb}\left(\mathrm{Fe}^{3+}\right)+\mathrm{NO}_{3}{ }^{-}$

Blood is the target organ. Blood contains an iron-based compound called haemoglobin $(\mathrm{Hb})$, which carries oxygen. When nitrite is present, $\mathrm{Hb}$ can be converted to methaemoglobin (metHb), which cannot carry oxygen. The normal metHb level in humans is less than $2 \%$ and in infant under 3 month of age is less than $3 \%$. The low level of metHb is maintained through a system of enzymatic functions that continually convert metHb back to $\mathrm{Hb}$ (WHO, 2007). When metHb concentrations reach $10 \%$ of normal $\mathrm{Hb}$ and above, symptoms of cyanosis (a bluish colour of skin and lips) usually appear. At higher concentrations, asphyxia may occur. Methylene blue is the specific antidote indicated in case of methaemoglobinaemia induced by nitrates and nitrites (WHO, 2003). Young infants less than 3 months of age are more susceptible to nitrite-induced methaemoglobinaemia because of the higher reduction of nitrate to nitrite by gastric bacteria due to the low production of gastric acid, the relatively easy oxidation of foetal $\mathrm{Hb}$, and the immaturity of the methaemoglobin reductase system (WHO, 2003). However, the risk of nitrite-induced methaemoglobinaemia of infants about 6 months of age should not be overlooked since solid food including vegetables are usually introduced around this age.

\section{Carcinogenicity}

Nitrite as such, and nitrate when reduced to nitrite, may react with amines or amides to form carcinogenic $\mathrm{N}$-nitroso compounds. 5 Nitrosation can occur mainly in two situations: (1) during storage and ripening of the food product and (2) in the stomach from the action of salivary nitrite produced through enzymatic reduction of endogenous or exogenous nitrate (Vittozzi, 1992). Several authors have suggested that the risk for the development of stomach cancer is positively correlated with three factors: (1) the nitrate level of drinking water, (2) the urinary excretion of nitrate and (3) the occurrence of atrophic gastritis. Epidemiological studies have not provided any evidence that there is an increased risk of cancer related to high nitrate intake from sources other than vegetables. In some cases studies revealed a negative correlation between nitrate intake and gastric cancer (Beresford, 1985) because vegetables are an excellent source of vitamins, minerals and biologically active compounds (Vermeer et al., 1998).

\section{Potential beneficial effects of nitrate}

There is evidence linking nitrate and nitrite to the prevention of microbial infections, reduction of hypertension and cardiovascular diseases (Santamaria, 2006). Nitric oxide and solutions of acidified nitrite, mimicking gastric conditions, have been shown to have antimicrobial activity against a wide range of organisms, in particular, gastrointestinal pathogens such as Yersinia and Salmonella. Thus nitrate in the form of nitric oxide may play a role in host defence (WHO, 2003). Nitric oxide is also known to have vasodilatory properties and to modulate platelet function. A recent study quoted by ESFA hypothesized that a high nitrate content of beetroot juice represented a vasoprotective nitric oxide via bioactivation. In healthy volunteers, approximately 3 hours after ingestion of $500 \mathrm{ml}$ of beetroot juice, a dietary nitrate load of $2.9 \mathrm{~g} / \mathrm{L}$, a significant reduction of blood pressure was observed $(-10.4 / 8 \mathrm{~mm} \mathrm{Hg})$ and this effect was correlated with peak increases in plasma nitrite concentration (ESPA, 2008). The potential beneficial effects of nitrate and nitrite subject to further study.

\section{Acceptable daily intake}

The concept of ADI is defined by the Joint Expert Committee of the Food and Agriculture (JECFA) Organization of the United Nations/World Health Organization (WHO) for substances intentionally added to food or for contaminants (pesticides, herbicides and fertilizers) (Gangolli et al., 1994). The JECFA and the European Commission's Scientific Committee on Food (SCF) have set an ADI for $\mathrm{NO}_{3}$ of $0-3.7 \mathrm{mg} \mathrm{kg}^{-1}$ bodyweight (SCF, 1997). The USA Environmental Protection Agency (EPA) Reference Dose (RfD) for nitrate is $1.6 \mathrm{mg}$ nitrate nitrogen $\mathrm{kg}^{-1}$ bodyweight (bw) per day (equivalent to about $7.0 \mathrm{mgNO}_{3} \mathrm{~kg}^{-1}$ bw per day) (Mensinga et al., 2003)

\section{Limits to maximum levels of nitrate in vegetables}

To protect public health in response to the SCF's considerations of nitrate in food, (SCS, 1997) in 1997 the European Member States agreed an EC Regulation setting limits for nitrate in lettuce and spinach. Limits to maximum levels of nitrate for trade in other vegetables are set in some European countries (Table 3). For potato, several countries have put forward the proposal of 'guidelines' for nitrate content (in Germany, for instance, only tubers with less than $200 \mathrm{mgkg}^{-1}$ fresh matter (fm) are accepted), while in Poland there is a maximum limit of $183 \mathrm{mgkg}^{-1} \mathrm{fm}$. (Cieslik and Sikora, 1998).

Table 3: Maximum levels (limits) of $\mathrm{NO}_{3}\left(\mathrm{mg} \mathrm{kg}^{-1} \mathrm{fm}\right)$ to trade various vegetables in some European countries

(Santamaria, 1997)

\begin{tabular}{|c|c|c|c|c|c|}
\hline Vegetable & Austria & Belgium & Germany & Netherlands Switzerland \\
\hline Carrot & 1500 & & & & \\
\hline Red beetroot & 4500 & & 3000 & 3500 & 3500 \\
\hline $\begin{array}{c}\text { Endive } \\
\text { (summer) }\end{array}$ & 2500 & 2000 & & 2500 & 2500 \\
\hline $\begin{array}{c}\text { Indivia } \\
\text { (winter) }\end{array}$ & 3500 & 2000 & & 3500 & 2500 \\
\hline Cabbage & 1500 & & & & 3500 \\
\hline Radish & & & & & \\
\hline $\begin{array}{c}\text { Celery } \\
\text { (green) }\end{array}$ & & 5000 & & & \\
\hline $\begin{array}{c}\text { Celery } \\
\text { (white) }\end{array}$ & & 4000 & & & \\
\hline $\begin{array}{c}\text { Lamb's } \\
\text { lettuce }\end{array}$ & & 3500 & 2500 & & \\
\hline
\end{tabular}

\section{Volume 4 Issue 12, December 2015}




\section{International Journal of Science and Research (IJSR) \\ ISSN (Online): 2319-7064}

Index Copernicus Value (2013): 6.14 | Impact Factor (2014): 5.611

\section{Strategies that can be undertaken}

The various approaches that may be adopted to reduce nitrate levels in vegetables are summarized below

- A balanced fertilization program for vegetable crops should be chalked out to ensure an adequate, but not excessive supply of nutrients for optimum yield and quality, and avoid or minimize nitrogen losses to the environment.

- Nitrate concentration in plants may be reduced by partial replacement of nitrate in the nutrient solution with ammonium urea, mixed amino acids, chloride or sulfate a few days prior to crop harvesting.

- There is a need to bridge the gap between research laboratories and farmers' fields. Decision-makers must formulate relevant agricultural policies encompassing education and training of farmers to make them understand the effects of nitrate on human health and the importance of nutrient management and other strategies for minimizing the nitrate content in plant tissues. Consumers also need to be educated regarding the nitrate content in vegetables and its health implications.

\section{Conclusion}

Epidemiological data provide conflicting evidence regarding the potential long-term health risks of nitrate levels encountered in the diet, it is widely accepted that the reduction of dietary nitrate is a desirable preventive measure. The maximum allowable nitrate levels in vegetables should not exceed levels that reflect good agricultural practices. Therefore, an integrated collaboration among agronomists, physiologists, molecular biologists, farmers, consumers and policy-makers is the need of the hour and may yield satisfactory results towards minimizing accumulation of nitrate in plants and its subsequent consumption by human beings.

\section{References}

[1] Andrews, M. (1986). The partitioning of nitrate assimilation between root and shoot of higher plants:mini-review. Plant Cell Environ., 9: 511-519.

[2] Anjana, Umar S., Iqbal M., Abrol Y.P. (2006) Are nitrate concentrations in leafy vegetables within safe limits? Proceedings of the Workshop on Nitrogen in Environment, Industry and Agriculture, New Delhi, India, pp. 81-84.

[3] Beresford, S.A. (1985). Is nitrate in drinking water associated with gastric cancer in the urban UK? Int $J$ Epidemiol., 14: 57-63.

[4] Chadjaa, H., Vezina, L.P., Dorais, M. and Gosselin A. (2001). Effects of lighting on the growth, quality and primary nitrogen assimilation of greenhouse lettuce (Lactuca sativa L.). Acta Hortic., 559, 325-331.

[5] Chen, B.M., Wang, Z.H., Wang, G.X., Song, H.X. and Wang, X.N. (2004). Effects of nitrate supply on plant growth, nitrate accumulation, metabolic nitrate concentration and nitrate reductase activity in three leafy vegetables. Plant Sci., $167:$ 635-643.

[6] Cieslik, E. and Sikora E. (1998). Correlation between the levels of nitrates and nitrites and the contents of potassium, calcium and magnesium in potato tubers. Food Chem., 63: 525-528.

[7] Custic, M., Poljak, M., Coga, L., Cosic, T., Toth, N. and Pecina M. (2003). The influence of organic and mineral fertilization on nutrient status, nitrate accumulation, and yield of head chicory. Plant Soil Environ., 49: 218-222.

[8] Dich, J., Jarvinen, R., Knekt, P. and Penttila, P.L. (1996). Dietary intakes of nitrate, nitrite and NDMA in the Finnish Mobile Clinic Health Examination Survey. Food Addit.Contam., 13, 541-552.

[9] Feng, J. (2006). Assessment of nitrate exposure in Beijing residunts via consumption of vegetables. Chinese Journal of Food Hygiene., 18(6): 514-516.

[10] Gangolli, S.D., Brandt, P., Feron, V. and Winshnok, J. (1994). Assessment of nitrate, nitrite, and N-nitroso compounds. Eur $J$ Pharmacol Environ Toxicol Pharmacol Sect., 292: 1-38.

[11] Harrison, J., Hirel, B. and Limani, A.M. (2004). Variation in nitrate uptake and assimilation between two ecotypes of Lotus japonicus and their recombinant inbred lines. Physiol. Plantarum., 120: 124-131.

[12] Maynard, D.N. and Barker, A.V. (1979). Regulation of nitrate accumulation in vegetables. Acta Hortic., 93 :153-162.

[13] McCall, D and Willumsen, J. (1999). Effects of nitrogen availability and supplementary light on the nitrate content of soil grown lettuce. J. Hortic. Sci. Biotech., 74: $458-463$

[14] Mensinga, T.T., Speijers, G.J.A. and Meulenbelt, J. (2003). Health implications of exposure to environmental nitrogenous compounds. Toxicol Rev., 22: 41-51.

[15] Merlo, I., Ferretti, C., Passera, C. and Ghisi R. (1994). Effect of decreased irradiance on $\mathrm{N}$ and $\mathrm{C}$ metabolism in leaves and roots of maize. Physiol. Plantarum., 91, 72-80.

[16] Santamaria, P. (1997). Contributo degli ortaggi all'assunzione giornaliera di nitrato, nitrito e nitrosammine. Industrie Alimentari 36 : 1329-1334.

[17] Santamaria, P. (2006). Review - Nitrate in vegetables: toxicity content, intake and EC regulation. Journal of Food Agriculture., 86: 10-17.

[18] Santamaria, P., Elia, A., Serio, F. and Todaro, E. (1999). A survey of nitrate and oxalate content in retail fresh vegetables. J. Sci. Food Agr., 79: 1882-1888.

[19] Santamaria, P., Elia, A., Gonnella, M., Parente, A., and Serio, F. (2001). Ways of reducing rocket salad nitrate content. Acta Hortic., 548, 529-537.

[20] SCF (Scientific Committee on Food). (1997). Assessment of dietary intake of nitrates by the population in the European Union, as a consequence of the consumption of vegetables, in Reports on tasks for scientific cooperation: report of experts participating in Task 3.2.3, ed by European Commission, Brussels, p 34.

[21] Speijers, G.J.A. (1996). Nitrate, in Toxicological evaluation of certain food additives and contaminants in food, ed by World Health Organization, Food Additives Series 35, Geneva, pp 325-360.

[22] Vermeer, T.M., Pachen, M.F., Dallinga, J.W., Kleinjans, J.C. and Maanen, M.S. (1998). Volatile Nnitrosamine formation after intake of nitrate at the ADI level in combination with an amine-rich diet. Environ Health Perspect., 106: 459-463. 


\section{International Journal of Science and Research (IJSR) \\ ISSN (Online): 2319-7064}

Index Copernicus Value (2013): 6.14 | Impact Factor (2014): 5.611

[23] Vieira, I.S., Vasconselos, E.P. and Monteiro A.A. (1998). Nitrate accumulation, yield and leaf quality of turnip greens in response to nitrogen fertilisation, Nutr. Cycl. Agroecosys., 51, 249-258.

[24] Vittozzi, L. (1992). Toxicology of nitrates and nitrites. Food Addit Contam., 9:579-585.

[25] Walker, R. (1990). Nitrates, nitrites and Nnitrosocompounds: a review of the occurrence in food and diet and the toxicological implications. Food Addit Contam 7: 717-768.

[26] WHO. (2003). Nitrate (and potential endogenous formation of $\mathrm{N}$-nitroso compounds). In: Safety evaluation of certain food additives (Food additives Series 50). Geneva: WHO; Available from: URL:http://www.inchem.org/documents/jecfa/jecmono/ v50je06.htm

[27] WHO. (2007). Nitrate and nitrite in drinking water background document for development of WHO Guidelines for Drinking-water Quality. Geneva: WHO.

URL:http://www.who.int/water_sanitation_health/dwq/ chemicals/nitratenitrite2ndadd.pdf

[28] Zhou, Z.Y., Wang, M. J. and Wang, J. S. (2000). Nitrate and nitrite contamination in vegetables in China. Food Rev. Int., 16, 61-76. 